MOVERS

Sally Benson, executive director, Global Climate and Energy Project, Stanford University, California

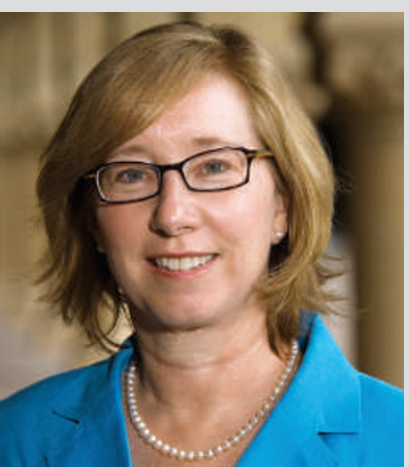

1980-2007: Staff scientist (director 1993-1997), Earth Sciences Division, Lawrence Berkeley National Laboratory, Berkeley, California 2001-2004: Deputy director for operations, Lawrence Berkeley National Laboratory 1997-2001: Associate laboratory director, Energy Sciences, Lawrence Berkeley National Laboratory

As an undergraduate at Barnard College, New York, Sally Benson loved both physics and natural history. A geology course at nearby Columbia University showed her a way to combine those interests. Designed to lure those with strong quantitative backgrounds away from physics and chemistry, it put Benson on track for a geology degree. "I imagined working on the geophysical properties of the mantle-core boundary of the planet," she says.

A summer job at the Department of Energy's Lawrence Berkeley National Laboratory (LBNL) set Benson on a long-term path as a geothermal-energy researcher and environmental problem solver. Her PhD dissertation topic - remediation of toxic selenium from the soils and water of Kesterson reservoir, a marsh in California - was one of the first studies to use the natural biogeochemistry as a remediation strategy for inorganic contaminants. She demonstrated that microbes played a key role in converting selenium to an immobile, non-toxic form. "This project led me to believe science could play an immediate role in environmental problem solving," she says.

Her ability to communicate science effectively swept her into administration, when she became director of the Earth sciences division at the LBNL. Certain that the team could provide solutions to major challenges, notably climate change, she kept an eye on emerging issues to develop the LBNL's portfolio of research in regional climate modelling, carbon-flux monitoring, carbon sequestration and geological storage of carbon dioxide. After a few years, she also became the associate laboratory director for the energy sciences. In 2004, she left management to focus on her interest in testing geological storage of carbon dioxide as a method of mitigating climate change.

On 1 March, however, Benson's experiences and interests coalesced when she became executive director of Stanford University's Global Climate and Energy Project (GCEP). She says it was the breadth of the endeavour - covering all aspects of carbon dioxide and climate-related problems - that motivated her move.

"No one can guess how market forces and research will play out over the next 30-50 years," says GCEP project director Franklin Orr. However, the LBNL's acting director of earth sciences, Ernie Major, says Benson's expertise lies in integrating all the research demands needed to find answers. And finding them is Benson's new passion. "It's a critical time to put solutions on the table," she says. Virginia Gewin
NETWORKS \& SUPPORT

\section{Opportunities in Poland}

A young Polish scientist recently expressed concern in this column about the paucity of opportunities in Poland for young repatriates hoping to establish independent research groups (see Nature 445, 792; 2007). We respectfully disagree.

Despite low science budgets and many old-fashioned procedures, there are institutes in Poland where postdocs can start independent careers.

Several newly formed groups conduct research at a high level and attract funds from outside Poland. Most are headed by postdocs who have returned after successes abroad.

For example, in 2005, one of us, Marta Miaczynska, returned after 12 years abroad in which she completed $\mathrm{PhD}$ and two postdocs in molecular cell biology. In 2003, she earned a position as a group leader at the International Institute of Molecular and Cell Biology in Warsaw (IIMCB).

Grants from the international programmes of the Howard Hughes Medical Institute (HMMI) and the Wellcome Trust helped her set up a new research group. Funding from the European Union, the Max Planck Society and the Polish Ministry of Science allowed her to build a nineperson research team and attract postdocs, including repatriates from abroad. We believe that such opportunities are increasing steadily.

Miaczynska returned to Poland because she believed she would be able to develop quality, independent research, with sufficient funds, in a supportive environment. Two years on, she does not regret her decision.

We are convinced that top young researchers can find attractive options if they are ready to compete for positions and funds. True, such opportunities are not yet common in Poland; it is not as easy as in richer countries with a more advanced research infrastructure. But those who are successful can apply to several sources for extra funding, and can select the very best PhD students from a large number of graduates.

We agree that the system needs reforms, in particular more young people on faculty staffs. Despite some recent initiatives, by the Foundation for Polish Science, for example, more needs to be done to facilitate early independence of young scientists and to attract our compatriots back. After all, if Polish scientists stay in other countries, who will push for changes to Polish science?

Jacek Kuznicki is director of the IIMCB in Warsaw, Poland. Marta Miaczynska is an HHMI international scholar and a cell biologist at the IIMCB.

\section{POSTDOC JOURNAL}

\section{Parent and mentor}

Although I've mentored several undergraduate students in the past, I hadn't realized what being a mentor was really about until I became a parent. Now I see that the similarities are uncanny.

When my student figures out something new or 'gets it', I feel proud and excited. When he shows up four hours late, I am disappointed that he didn't warn me, and frankly, I feel that I should scold him (though I don't). I find myself explaining, in great detail, simple things that I take for granted as routine or obvious. Other times, I find him plugging away at data analyses I hadn't expressly told him to work on. Just like any parent, I take his successes, and failures, personally.

In my pre-parenting days, I had assumed that good students were born. But I now realize they are made, through careful and patient nurturing by scientists who are willing to devote their time.

My mentoring experience has taught me how to be a more patient teacher, a good listener and a better planner. Every student, successful or not, is unique and each can teach me something new and useful about myself. Of course, the best part of mentoring, for me, is watching their intellect and creativity shine as they progress in their projects, and watching their careers blossom when they leave the nest as they, perhaps, go on to nurture their own students.

Moira Sheehan is a postdoc in plant breeding and genetics at Cornell University. 